\title{
Detection of multiple viral DNA species in synovial tissue and fluid of patients with early arthritis
}

Hans-Detlev Stahl, Bernd Hubner, Bernd Seidl, Uwe G Liebert, Ineke M van der Heijden, Bert Wilbrink, Maarten C Kraan, Frank Emmrich, Paul P Tak

Institute of Clinical Immunology and Transfusion Medicine, University of Leipzig, Leipzig, Germany H-D Stahl

B Seidl

F Emmrich

Institute of Anatomy, University of Leipzig B Hubner

Institute of Virology, University of Leipzig U G Liebert

Department of Rheumatology, Leiden University Medical Centre, Leiden, The Netherlands

I $M$ van der Heijden

Research Laboratory for Infectious Diseases, National Institute of Public Health and the Environment (RIVM), Bilthoven, The Netherlands

B Wilbrink

Division of Clinical Immunology and Rheumatology, Department of Internal Medicine, Academic Medical Centre, Meibergdreef 9, PO Box 22660, 1100 DD Amsterdam, The Netherlands

M C Kraan

P P Tak

Correspondence to: Professor Tak

Email: P.P.Tak@amc.uva.nL

Accepted for publication 5 January 2000

\begin{abstract}
Objective-Viruses have a role in the pathogenesis of various forms of arthritis. This study aimed at determining whether viral DNA can be detected in joint samples in the early stages of idiopathic arthritides.

Methods-Synovial fluid (SF) and synovial tissue (ST) samples were obtained from 73 patients, with undifferentiated arthritis $(n=22)$, rheumatoid arthritis $(n=13)$, spondyloarthropathy $(n=17)$, crystal arthropathy $(\mathrm{n}=8)$, osteoarthritis $(n=7)$, septic arthritis $(n=5)$, and trauma $(n=1)$. The presence of viral DNA was investigated by polymerase chain reaction analysis.

Results-Cytomegalovirus was present in 25 patients, parvovirus $B 19$ in 15 patients, Epstein-Barr virus in 12 patients, and herpes simplex virus in 16 patients (in $S T$, $\mathrm{SF}$, or both), respectively. The joint samples were negative for viral DNA from adenovirus and varicella-zoster virus. In ST, eight patients were double positive for parvovirus B19 and another viral DNA, with herpes simplex virus being the most prevalent. Seven patients were double positive for other viruses (cytomegalovirus, herpes simplex virus, Epstein-Barr virus). In SF, four patients were double or triple positive for viral DNA. Paired samples were available in 56 patients. In these, viral DNA was detected in 37 patients in ST, as compared with 19 in SF.

Conclusion-These data show that one or more viruses can be detected in the synovial specimens of patients with early arthritis, irrespective of the clinical diagnosis. This observation might be explained by migration of inflammatory cells harbouring viral DNA into the inflamed joints.

(Ann Rheum Dis 2000;59:342-346)
\end{abstract}

Viruses have a role in the pathogenesis of various forms of rheumatic diseases. ${ }^{1}$ For instance, parvovirus B19 infection in adults is characterised by, a usually self limiting, symmetrical polyarthritis of the small joints of the hands, the wrists, and the knees. ${ }^{2}$ Although parvovirus B19 DNA has been detected in synovial tissues (ST) of patients with rheumatoid arthritis (RA), ${ }^{3}$ its role in causing this disease has been questioned. ${ }^{3-6}$ Retroviruses have been observed in ST biopsy specimens from patients with RA, but also in non-inflammatory arthropathy and normal controls. ${ }^{7-8}$ Searches for other viruses, such as Epstein-Barr virus, ${ }^{9-11}$ rubella virus, ${ }^{12}$ mumps virus, ${ }^{12}$ measles virus, ${ }^{12}$ cytomegalovirus, ${ }^{13} 14$ and adenovirus ${ }^{15}{ }^{16}$ did not clearly support a specific role in the pathogenesis of RA either.

This could theoretically be different for other viruses and for other forms of arthritis, especially for patients with so-called undifferentiated arthritis, a term used when no specific cause can be determined and when the patient does not fulfil generally accepted criteria for a particular rheumatic disease. ${ }^{17}$ Of note, this form could sometimes represent an early stage of RA, representing therefore a suitable target in the search for potentially disease-specific viruses. Alternatively, viral DNA might be present in various forms of arthritis owing to non-specific migration of macrophages and other inflammatory cells containing viral particles into the inflamed joints. We recently proposed a similar model for migration of inflammatory cells harbouring bacterial DNA, ${ }^{18-20}$ which could subsequently promote synovial inflammation. ${ }^{21}$ To provide more insight into the possible role of viruses in patients with arthritis we studied the presence of viral DNA in joint samples by polymerase chain reaction (PCR).

Patients, materials, and methods PATIENTS AND CLINICAL SPECIMENS

Seventy three patients with arthritis in at least one knee joint were included in the study. All patients had a disease duration of less than one year. ST was available from 68 patients and synovial fluid (SF) from 61 patients. Twenty two patients had undifferentiated arthritis, ${ }^{17}$ based on the exclusion of other rheumatic diseases (10 patients had a monarthritis, nine oligoarthritis, and three polyarthritis). The other patients presented with the following diagnoses: crystal arthropathies (eight), rheumatoid arthritis (13), ${ }^{22}$ osteoarthritis (seven), ${ }^{23}$ spondyloarthropathy (17), ${ }^{24}$ septic (bacterial) arthritis (five), and trauma (one). The study was approved by the medical ethics committees of the Leiden University Medical Centre and the University of Leipzig.

\section{DNA EXTRACTION}

SF (61) or ST (68) samples, or both, were collected from swollen knee joints using the Parker-Pearson biopsy procedure with several modifications, as described previously. ${ }^{18}$ The 
Table 1 Primers used for polymerase chain reaction (PCR) amplification

\begin{tabular}{|c|c|c|c|c|}
\hline Pathogen & Primer & Sequence & Amplified genome region & Product size (bp) \\
\hline \multirow[t]{2}{*}{ Adenovirus $^{36}$} & A1 & 5'- TAC GCC AAC TCC GCC CAC GCG CTA (forward) & Hexon region & 161 \\
\hline & $\mathrm{A} 2$ & 5'- GCC GAG AAG GGC CTG CGC AGG TA (reverse) & & 161 \\
\hline \multirow[t]{4}{*}{ Cytomegalovirus $^{26}$} & ex1 & 5 - CCA AGC GGC CTC TGA TAA CCA AGC C (forward) & Major IE antigen region (external) & 435 \\
\hline & $\mathrm{ex} 2$ & 5'- CAG CAC CAT CCT CCT CCT CCT CTG G (reverse) & & 435 \\
\hline & in 1 & 5'- AGA GTC TGC TCT CCT AGT GTG (forward) & Major IE antigen region (internal) & 280 \\
\hline & in 2 & 5'- AGA CAC TGG CTC AGA CTT GAC (reverse) & & 280 \\
\hline \multirow[t]{4}{*}{ Epstein-Barr virus ${ }^{27}$} & $\mathrm{E} 2 \mathrm{P} 1$ & 5'- AGG GAT GCC TGG ACA CAA GA (forward) & EBNA2 gene (external) & 596 \\
\hline & $\mathrm{E} 2 \mathrm{P} 2$ & 5'- TGG TGC TGC TGG TGG TGG CAA T (reverse) & & 596 \\
\hline & Ap1 & 5'- TCT TGA TAG GGA TCC GCT AGG ATA (forward) & EBNA2 gene (internal) & 497 \\
\hline & Ap2 & 5'- ACC GTG GTT CTG GAC TAT CTG GAT C (reverse) & & 497 \\
\hline \multirow[t]{2}{*}{ Herpes simplex virus ${ }^{28}$} & e1 & 5'- CAG AAC TAC ACG GAG GGC ATC (forward) & Glycoprotein $\beta$ gene (external) & 136 \\
\hline & $\mathrm{e} 2$ & 5'- TCC CCA TAA ACT GGG AGT AGC (reverse) & & 136 \\
\hline \multirow[t]{4}{*}{ Parvovirus B19 $9^{29}$} & P1 & 5'- AAT ACA CTG TGG TTT TAT GGG CCG (forward) & NS1 region (external) & 283 \\
\hline & P6 & 5'- CCA TTG CTG GTT ATA ACC ACA GGT (reverse) & & 283 \\
\hline & P2 & 5'- AAT GAA AAC TTT CCA TTT AAT GAT GTA G & NS1 region (internal) & 102 \\
\hline & P5 & 5'- CTA AAA TGG CTT TTG CAG CTT CTA C (reverse) & & 102 \\
\hline \multirow{4}{*}{ Varicella-zoster virus $^{30}$} & VZV1 & 5'- ATG TCC GTA CAA CAT CAA CT (forward) & $X b a \mathrm{I} M$ region (external) & 267 \\
\hline & VZV2 & 5'- CGA TTT TCC AAG AGA GAC GC (reverse) & & 267 \\
\hline & VZV3 & 5'- GCC CAT GAA TCA CCC TCT TGT (forward) & $X b a I$ M region (internal) & 125 \\
\hline & VZV4 & 5'- CGT GCT ATT GAA GTC GTC TCC (reverse) & & 125 \\
\hline
\end{tabular}

Internal and external primers were used in nested PCR, according to the respective protocols (see "Methods" for details).

samples used for DNA extraction $(500 \mu \mathrm{l}$ of $\mathrm{SF}$, and six to eight synovial biopsy specimens) were transferred into digestion buffer containing proteinase $\mathrm{K}$ and incubated for 18 hours at $60^{\circ} \mathrm{C}$ to release total DNA, as described previously. ${ }^{18}$ During the collection of the SF and ST biopsy samples in the outpatient procedure room and also during the transfer of SF and ST into digestion buffer in a biosafety hood, control vials with digestion buffer were opened and closed simultaneously with sample collection vials (collection controls). DNA extraction was performed in a safety hood, which was equipped with ultraviolet germicidal lamps, in separate, specifically dedicated, positive pressure laboratories $(>10 \mathrm{~Pa})$ with a lockgate. Dedicated pipettes with disposable filter tips, disposable gloves and laboratory coats, and non-reusable waste containers were used. The reagents from different manufacturers or different batches from a reagent, or both, were tested before application of the PCR on patient samples. Negative controls also consisted of digestion buffer without patient material, which were handled in the same way as the samples obtained from the patients. Finally, DNA was also obtained from ST of patients with non-detectable serum antibodies against the viruses under investigation and which were negative by PCR analysis in previous studies.
PCR TESTING OF SYNOVIAL DNA AND RNA

PCR experiments were performed, as described previously. ${ }^{25-30}$ DNA extraction, pipetting of each sample, PCR amplification, and electrophoresis were performed in separate rooms. Table 1 shows the primers used. All amplifications except for adenovirus and herpes simplex virus were carried out by nested PCR, using a thermal cycler 2400 (PerkinElmer Cetus, Weiterstadt, FRG). Positive samples were tested a second time and they were only classified as positive when the result of the first test could be confirmed independently.

The following positive controls were used for PCR analysis: herpes simplex virus (types I and II): vero cell culture infected with patient material, tested by immunofluorescence using monoclonal antibodies; varicella-zoster virus: human fibroblasts infected with the OKA strain; cytomegalovirus: human diploid fibroblasts infected with the AD 169 strain; adenovirus: HeLa cells, transfected with the APC1 strain; parvovirus B19 NS1 sequence: positive patient serum and VP2 gene segment: baculovirus recombinant AcB19VP1L expressing VP1 protein of human parvovirus B19 (kindly provided by Professor W Spaan, Leiden ${ }^{31}$ ); Epstein-Barr virus: Epstein-Barr virus immortalised B lymphocytes. As a positive control for the PCR procedure the housekeeping gene for

Table 2 Detection of various viral DNA in patients for whom both synovial tissue and synovial fluid were available

\begin{tabular}{|c|c|c|c|c|}
\hline & $\begin{array}{l}\text { Parvovirus B19 } \\
(n=56)\end{array}$ & $\begin{array}{l}\text { Epstein-Barr virus } \\
(n=53)\end{array}$ & $\begin{array}{l}\text { Herpes simplex virus } \\
(n=54)\end{array}$ & $\begin{array}{l}\text { Cytomegalovirus } \\
(n=55)\end{array}$ \\
\hline \multicolumn{5}{|l|}{ Synovial fluid } \\
\hline Undiff. arthritis & $1 / 16$ & $0 / 16$ & $1 / 16$ & $2 / 16$ \\
\hline Spondyloarthropathy & $1 / 14$ & $1 / 13$ & $2 / 13$ & $3 / 14$ \\
\hline Rheumatoid arthritis & $0 / 11$ & $2 / 10$ & $1 / 10$ & $3 / 11$ \\
\hline Osteoarthritis & $0 / 7$ & $1 / 7$ & $1 / 7$ & $1 / 7$ \\
\hline Crystal arthritis & $0 / 7$ & $0 / 6$ & $0 / 7$ & $2 / 6$ \\
\hline Trauma & $0 / 1$ & $0 / 1$ & $0 / 1$ & $0 / 1$ \\
\hline \multirow[t]{2}{*}{ Total (No (\%)) } & $2 / 56(4)$ & $4 / 53(8)$ & $5 / 54(9)$ & $11 / 55(20)$ \\
\hline & $\begin{array}{l}\text { Parvovirus B19 } \\
(n=56)\end{array}$ & $\begin{array}{l}\text { Epstein-Barr virus } \\
(n=52)\end{array}$ & $\begin{array}{l}\text { Herpes simplex virus } \\
(n=54)\end{array}$ & $\begin{array}{l}\text { Cytomegalovirus } \\
(n=55)\end{array}$ \\
\hline \multicolumn{5}{|l|}{ Synovial tissue } \\
\hline Undiff. arthritis & $2 / 16$ & $4 / 15$ & $3 / 16$ & $5 / 16$ \\
\hline Spondyloarthropathy & $6 / 14$ & $1 / 13$ & $3 / 13$ & $5 / 14$ \\
\hline Rheumatoid arthritis & $2 / 11$ & $2 / 10$ & $2 / 10$ & $3 / 11$ \\
\hline Osteoarthritis & $1 / 7$ & $1 / 7$ & $2 / 7$ & $5 / 7$ \\
\hline Crystal arthritis & $0 / 7$ & $1 / 6$ & $1 / 7$ & $2 / 6$ \\
\hline Trauma & $0 / 1$ & $0 / 1$ & $0 / 1$ & $0 / 1$ \\
\hline Total (No (\%)) & $11 / 56(20)$ & 9/52 (17\%) & $11 / 54(20)$ & $20 / 55(36)$ \\
\hline
\end{tabular}


Table 3 Detection of various viral DNA in synovial tissue or synovial fluid

\begin{tabular}{lllll}
\hline & $\begin{array}{l}\text { Parvovirus B19 } \\
(n=5)\end{array}$ & $\begin{array}{l}\text { Epstein-Barr virus } \\
(n=5)\end{array}$ & $\begin{array}{l}\text { Herpes simplex virus } \\
(n=5)\end{array}$ & $\begin{array}{l}\text { Cytomegalovirus } \\
(n=5)\end{array}$ \\
\hline $\begin{array}{l}\text { Synovial fluid } \\
\text { Undiff. arthritis }\end{array}$ & $0 / 1$ & $0 / 1$ & & $0 / 1$ \\
$\quad$ Septic arthritis & $1 / 4$ & $1 / 4$ & $3 / 4$ & $2 / 4$ \\
$\quad$ Total (No (\%)) & $1 / 5(20)$ & $1 / 5(20)$ & $3 / 5(60)$ & $2 / 5(40)$ \\
& & & & \\
& Parvovirus B19 & Epstein-Barr virus & Herpes simplex virus & Cytomegalovirus \\
& $(n=12)$ & $(n=12)$ & $(n=12)$ & \\
Synovial tissue & & & & $1 / 5$ \\
Undiff. arthritis & $0 / 5$ & $1 / 5$ & $0 / 5$ & $2 / 3$ \\
Spondyloarthropathy & $0 / 3$ & $0 / 3$ & $0 / 3$ & $0 / 2$ \\
Rheumatoid arthritis & $1 / 2$ & $0 / 2$ & $0 / 2$ & $0 / 1$ \\
Crystal arthritis & $0 / 1$ & $0 / 1$ & $1 / 1$ & $3 / 12(25)$ \\
Septic arthritis & $0 / 1$ & $1 / 1$ & $1 / 12(8)$ & \\
Total (No (\%)) & $1 / 12(8)$ & $2 / 12(17)$ & & \\
\hline
\end{tabular}

Table 4 Detection of multiple viral DNA in synovial tissue of patients with different rheumatic diseases

\begin{tabular}{lllllll}
\hline & $\begin{array}{l}\text { Parvovirus } \\
\text { B19 and } \\
\text { herpes simplex } \\
\text { virus }\end{array}$ & $\begin{array}{l}\text { Parvovirus B19 } \\
\text { and } \\
\text { cytomegalovirus }\end{array}$ & $\begin{array}{l}\text { Epstein-Barr } \\
\text { virus and } \\
\text { cytomegalovirus }\end{array}$ & $\begin{array}{l}\text { Herpes simplex } \\
\text { virus and } \\
\text { cytomegalovirus }\end{array}$ & $\begin{array}{l}\text { Epstein-Barr } \\
\text { virus and } \\
\text { herpes simplex } \\
\text { virus }\end{array}$ & $\begin{array}{l}\text { Number of } \\
\text { positive } \\
\text { patients (\%) }\end{array}$ \\
\hline Undifferentiated arthritis & 1 & 0 & 1 & 0 & 1 & $3 / 21(14)$ \\
Spondyloarthropathy & 2 & 1 & 0 & 0 & 1 & $4 / 16(25)$ \\
Rheumatoid arthritis & 1 & 1 & 1 & 0 & 0 & $3 / 13(23)$ \\
Osteoarthritis & 1 & 0 & 1 & 1 & 0 & $3 / 7(43)$ \\
Crystal arthritis & 0 & 0 & 1 & 0 & 0 & $1 / 8(13)$ \\
Septic arthritis & 1 & 0 & 0 & 0 & 0 & $1 / 1(100)$ \\
Trauma & 0 & 0 & 0 & 0 & 0 & $0 / 1(0)$
\end{tabular}

GAP-DH was amplified. Randomly chosen samples were used for photometric determination of DNA concentration, which varied from 300 to $600 \mathrm{ng} / \mu \mathrm{l}$. For PCR analysis a total amount of at least $300 \mathrm{ng}$ was used. The laboratory investigators in Germany were blinded to the clinical diagnoses of the patients from the Netherlands.

\section{Results}

All positive controls were positive and the negative controls were negative. PCR analysis of ST was positive for cytomegalovirus in 23 patients, parvovirus B19 in 12 patients, Epstein-Barr virus in 11 patients, and herpes simplex virus in 12 patients (tables 2 and 3). DNA from adenovirus or varicella-zoster virus was not detected in the ST of any of the patients. There was no correlation between the presence of viral DNA and the clinical diagnosis or the serum levels of acute phase reactants (data not shown). As shown in tables 2 and 3, there were some small differences in patient numbers, because in some cases there was insufficient DNA for all PCR analyses.

Fifteen patients were double positive for different viral DNA species. Also, these double positives were scattered evenly over the diagnostic groups (table 4).

Paired samples of ST and SF were available from 56 patients. SF analysis showed essentially the same pattern as ST analysis, but with a lower incidence of positive results (tables 2 and 3). Viral DNA was detected in 37 patients in ST compared with 19 positive SF samples. Some of these specimens were double or triple positive for viral DNA. If SF samples were positive, ST biopsy specimens were also positive, except for one case with parvovirus B19 DNA only in the SF. This patient was positive for Epstein-Barr virus and cytomegalovirus DNA in the ST. In three patients
Epstein-Barr virus was detected in both SF and ST. However, parvovirus B19 was found in the SF in only one patient, whereas ST was positive in 11 cases. Twenty patients were positive for cytomegalovirus in ST and, of these, 11 were positive in $\mathrm{SF}$ as well. Herpes simplex virus was found in the SF of five of the 11 patients with a positive result in ST.

\section{Discussion}

PCR analysis was used to investigate the presence of DNA from several viruses in joint samples from patients with various forms of early arthritis. DNA from either parvovirus B19, Epstein-Barr virus, herpes simplex virus, or cytomegalovirus could be detected in the ST from 13 of the 22 patients with undifferentiated arthritis. The findings were not specific for any type of arthritis: viral DNA was present in joint samples from some patients with undifferentiated arthritis, spondyloarthropathy, RA, inflammatory osteoarthritis, crystal arthropathy, and bacterial arthritis. Fifteen patients were double positive for different viral DNA species. DNA from adenovirus and varicellazoster virus was not found in any patient. The findings confirm and extend previous studies. New observations are the presence of viral DNA in undifferentiated arthritis, the simultaneous presence of DNA from several viral species, and the finding that DNA from some viruses can be detected more often in synovial tissue than in synovial fluid.

According to the protocols used in this study the sensitivity of the PCR reaction can be estimated on at least 1-100 genome equivalentsthat is, a sensitivity sufficient for the analysis of at least $600 \mathrm{ng}$ total DNA, as used here. Paired samples of ST and SF were available in 56 patients. Overall, if SF samples were positive, ST samples were also positive. In one patient, however, parvovirus B19 DNA was found in 
the SF but not in the ST, even after several replicate analyses with the corresponding probe. Degradation of DNA and the presence of inhibitory substances were excluded by GAP-DH PCR and contamination was excluded by the negative controls, as described. This suggests that, in rare cases, the distribution of viral DNA is not homogeneous in the ST.

On the other hand, viral DNA was detected in 37 patients (total 51 cases) in ST as compared with 19 (total 22 cases) in SF. The difference in the detection of viral DNA between ST and SF depends on the type of virus under investigation. For Epstein-Barr virus it seemed to be of little importance whether ST or SF was used. However, ST samples were substantially more often positive for parvovirus B19, cytomegalovirus, and herpes simplex virus than SF samples. Thus it may be advantageous to use biopsy specimens rather than fluid aspirates for the detection of viral DNA in joint samples.

In this study as many as two thirds of the patients with various forms of early inflammatory arthritis harboured viral DNA in their joints. In addition, about $20 \%$ of the patients were positive for DNA of two viral species. The detection of viral DNA in the joints of patients with arthritis, however, does not necessarily indicate the presence of infectious viruses. Obviously, PCR analyses do not allow any conclusion to be drawn about the completeness of the viral genome or the potential of viral replication. Moreover, the fact that viral DNA was not only detected in undifferentiated arthritis, RA, and spondyloarthropathy but also in arthritides with diverse pathogenesesfor example, crystal induced arthropathy and osteoarthritis, does not substantiate a significant aetiological role for the viruses investigated in the clinically manifest phases of chronic arthritides of unknown cause. Of course this does not exclude a role for these viruses as initiating agents in the earliest phases of the disease. We have previously shown in patients with RA that so-called early arthritis may already represent a chronic phase of the disease. ${ }^{32} 33$

A tempting speculation is that the presence of viral DNA in various arthritides, as described here, is secondary to the migration of macrophages or other cells, harbouring viral DNA, into the synovial compartment. Similarly, this mechanism might explain the presence of bacterial DNA in joint samples from arthritic patients. ${ }^{18-20}$ Other mechanisms may also play a part. For instance, herpes simplex virus is known to be activated in neuronal axons by inflammatory cytokines, such as interleukin 1 and tumour necrosis factor $\alpha^{34}$ Thus the inflamed synovium, which produces a variety of proinflammatory cytokines, might activate latent viruses. These mechanisms could also explain the presence of DNA from two or more viruses in the joint samples. Even when the presence of viruses is a secondary phenomenon, they may still play a part in the pathogenesis of arthritis as viral antigens could further enhance synovial inflammation. In addition, partially breaking tolerance is not necessarily sufficient to cause autoimmunity. ${ }^{35}$ A second step of conditioning of the inflammatory milieu by infectious agents may enable activated $\mathrm{T}$ cells to cause tissue damage. ${ }^{35}$

Taken together, viral material of one or more viruses can be detected in ST and SF samples of some patients with early arthritis by PCR analysis, irrespective of the clinical diagnosis, indicating that detection of viral DNA in joint samples has limited diagnostic potential. This phenomenon is presumably the result of the non-specific migration of inflammatory cells containing viral particles into the synovial compartment, where they can promote synovial inflammation.

This work was supported by the Bundesministerium für Bildung, Forschung und Technologie $(\mathrm{BMB}+\mathrm{F})$, Interdisziplinäres Zentrum für Klinische Forschung (IZKF) at the University of Leipzig (Project A1), an HSP3-grant by the Ministerium für Wissenschaft und Kunst (SMWK) of Saxony, and The Dutch Arthritis Foundation (Het Nationaal Reumafonds) grant number 94-637.

1 Phillips PE. Viral arthritis. Curr Opin Rheumatol 1997;9:337-44

2 Reid DM, Reid TM, Brown T, Rennie JA, Eastmond CJ. Human parvovirus-associated arthritis: a clinical and laboratory description. Lancet $1985 ; \mathrm{i}: 422-5$.

3 Takahashi Y, Murai C, Shibata S, Munakata Y, Ishii T, Ishii $\mathrm{K}$, et al. Human parvovirus B19 as a causative agent for rheumatoid arthritis. Proc Natl Acad Sci USA 1998;95: 8227-32.

4 Saal JG, Steidle M, Einsele H, Muller CA, Fritz P, Zacher J. Persistence of B19 parvovirus in synovial membranes of patients with rheumatoid arthritis. Rheumatol Int 1992;12: $147-51$

5 Nikkari S, Luukkainen R, Mottonen T, Meurman O, Hannonen P, Skurnik M, et al. Does parvovirus B19 have a role in rheumatoid arthritis? Ann Rheum Dis 1994;53: 106-11.

6 Speyer I, Breedveld FC, Dijkmans BAC. Human parvovirus B19 infection is not followed by inflammatory joint disease during long term follow-up. A retrospective study of 54 patients. Clin Exp Rheumatol 1998;16:576-8.

7 Nakagawa K, Brusic V, McColl G, Harrison LC. Direct evidence for the expression of multiple endogenous retroviruses in the synovial compartment in rheumatoid arthritis. Arthritis Rheum 1997;40:627-38.

8 Griffiths DJ, Cooke SP, Herve C, Rigby SP, Mallon E, Hajeer A, et al. Detection of human retrovirus 5 in patients with arthritis and systemic lupus erythematosus. Arthritis Rheum 1999;42:448-54.

9 Takei M, Mitamura K, Fujiwara S, Horie T, Ryu J, Osaka S, et al. Detection of Epstein-Barr virus-encoded small RNA et al. Detection of Epstein-Barr virus-encoded small RNA 1 and latent membrane protein 1 in synovial lining cells 739-43.

10 Mousavi-Jazi M, Bostrom L, Lovmark C, Linde A, Brytting $M$, Sundqvist VA. Infrequent detection of cytomegalovirus and Epstein-Barr virus DNA in synovial membrane of patients with rheumatoid arthritis. J Rheumatol 1998;25: 623-8.

11 Zhang L, Nikkari S, Skurnik M, Ziegler T, Luukkainen R, Mottonen $\mathrm{T}$, et al. Detection of herpesviruses by polymerase chain reaction in lymphocytes from patients with rheumatoid arthritis. Arthritis Rheum 1993;36:1080-6.

12 Zhang D, Nikkari S, Vainionpaa R, Luukkainen R, Ylikerttula U, Toivanen P. Detection of rubella, mumps, and measles virus genomic RNA in cells from synovial fluid and peripheral blood in early rheumatoid arthritis. J Rheumatol 1997;24:1260-5.

13 Einsele H, Steidle M, Muller CA, Fritz P, Zacher J, Schmidt $\mathrm{H}$, et al. Demonstration of cytomegalovirus (CMV) DNA $\mathrm{H}$, et al. Demonstration of cytomegalovirus (CMV) DNA and anti-CMV response in the synovial membrane and serum of patients

14 Newkirk MM, Watanabe Duffy KN, Leclerc J, Lambert N, Shiroky JB. Detection of cytomegalovirus, Epstein-Barr virus and herpes virus- 6 in patients with rheumatoid arthritis with or without Sjögren's syndrome. Br J Rheumatol 1994;33:317-22.

15 Hart H, Norval M. Search for viruses in rheumatoid macrophage-rich synovial cell populations. Ann Rheum Dis 1980;39:159-63.

16 Nikkari S, Luukkainen R, Nikkari L, Skurnik M, Toivanen $P$. No evidence of adenoviral hexon regions in rheumatoid synovial cells and tissue. J Rheumatol 1994;21:2179-83.

17 Hulsemann JL, Zeidler H. Undifferentiated arthritis in an early synovitis out-patient clinic. Clin Exp Rheumatol 1995;13:37-43.

18 Wilbrink B, Van der Heijden IM, Schouls LM, Van Embden JDA, Hazes JMW, Breedveld FC, et al. Detection of bacterial DNA in joint samples from patients with undifferenti- 
ated arthritis and reactive arthritis, using polymerase chain reaction with universal 16S ribosomal RNA primers. Arthritis

Wilbrink B, Schouls LM, Breedveld FC, Tak PP. Detection of mycobacteria in joint samples from patients with arthritis using a genus-specific PCR and sequence analysis. Rheumatology (Oxford) 1999;38:54753.

20 Van der Heijden IM, Wilbrink B, Tchetverikov I, Schrijver I, Schouls LM, Van Embden JDA, et al. The presence of bacterial DNA and bacterial peptidoglycans in the joints of patients with rheumatoid arthritis and other arthritides. Arthritis Rheum (in press)

21 Deng GM, Nilsson IM, Verdrengh M, Collins LV, Tarkowski A. Intra-articularly localized bacterial DNA containing CpG motifs induces arthritis. Nat Med 1999;5: 702-5.

22 Arnett FC, Edworthy SM, Bloch DA, McShane DJ, Fries $\mathrm{JF}$, Cooper NS, et al. The American Rheumatism AssociaJF, Cooper NS, et al. The American Rheumatism Association 1987 revised criteria for the classification of

23 Altman R, Asch ES, Bloch DA, Bole G, Borenstein D, Brandt K, et al. Development of criteria for the classification and osteoarthritis of the knee. Arthritis Rheum 1986;29:103949.

24 Dougados M, van der Linden SM, Juhlin R, Huitfeldt B, Amor B, Calin A, et al. The European Spondylarthropathy
Study Group preliminary criteria for the classification of spondylarthropathy. Arthritis Rheum 1991;34:1218-27.

25 McCachren SS. Expression of metalloproteinases and metalloproteinase inhibitor in human arthritic synovium. Arthritis Rheum 1991;34:1085-93.

26 Demmler GJ, Buffone GJ, Schimbor CM, May RA. Detection of cytomegalovirus in urine from newborns by using polymerase chain reaction DNA amplification. J Infect Dis 1988;158:1177-84.

27 Telenti A, Uehlinger DE, Marchesi F, Germann D, Malinverni R, Matter L. Epstein-Barr virus infection in HIV-positive patients. Eur J Clin Microbiol Infect Dis 1993;12:601-9.

28 Dahm C, Pohl-Koppe A, ter Meulen V, Braun EW, Kuhn JE. Diagnosis of herpes-simplex virus encephalitis (HSVE) by polymerase chain reaction. In: Schumacher HC, Marx P, Rolfs A, eds. PCR topics, usage of polymerase chain reaction in genetic and infectious diseases. Berlin, Heidelberg, New York: Springer, 1990:113-16.

29 Durington EL, Erdman DD, Gary GW, Pallansch MA, Torok TJ, Anderson LJ. Multiple primer pairs for polymerase chain reaction (PCR) amplification of human parvovirus B19 DNA. J Virol Methods 1993;44:155-65.

30 Puchhammer-Stockl E, Popow-Kraupp T, Heinz FX, Mandl CW, Kunz C. Detection of varicella-zoster virus DNA by polymerase chain reaction in the cerebrospinal fluid of patients suffering from neurological complications associated with chicken pox or herpes zoster. J Clin Microbiol 1991;29:1513-16.

31 Brown CS, Salimans MM, Noteborn MH, Weiland HT. Antigenic parvovirus B19 coat proteins VP1 and VP2 produced in large quantities in a baculovirus expression system. Virus Res 1990;15:197-211.

32 Tak PP, Smeets TJM, Daha MR, Kluin PM, Meijers KAE, Brand R, et al. Analysis of the synovial cellular infiltrate in early rheumatoid synovial tissue in relation to local disease activity. Arthritis Rheum 1997;40:217-25.

33 Kraan MC, Versendaal H, Jonker M, Bresnihan B, Post W, 't Hart BA, et al. Asymptomatic synovitis precedes clinically manifest arthritis. Arthritis Rheum 1998;41:1481-8.

34 Walev I, Dienes HP, Bohl J, Podlech J, Falke D. Correlation of virus replication, cytokine (TNF-alpha and IL-1) producing cells, neuronal necrosis and inflammation after intranasal infection of mice with herpes simplex virus strains of different virulence. Arch Virol 1995;140:195767.

35 Limmer A, Sacher T, Alferink J, Kretschmar M, Schonrich $G$, Nichterlein $T$, et al. Failure to induce organ-specific autoimmunity by breaking of tolerance: importance of the microenvironment. Eur J Immunol 1998;28:2395-406.

36 Hierholzer JC, Halonen PE, Dahlen PO, Bingham PG, McDonough MM. Detection of adenovirus in clinical specimens by polymerase chain reaction and liquid-phase hybridization quantitated by time-resolved fluorometry. J Clin Microbiol 1993;31:1886-91. 